\title{
Sweetwater Sound: The WHY, HOW, and WHAT Behind the Success
}

\author{
Robert Willey \\ Ball State University \\ This paper was presented at the 2019 International Summit of the \\ Music \& Entertainment Industry Educators Association \\ March 21-23, 2019
}

https://doi.org/10.25101/19.43

\section{Abstract}

Sweetwater founder and CEO Chuck Surack started out as a musician and later launched a mobile recording service. He became an expert in the Kurzweil K250 - the first synthesizer to incorporate digital technology — and then sold the instrument and the custom sample libraries he developed for it to top recording artists along with other equipment they asked for and gradually grew his customer base. Surack's music retail company, Sweetwater Sound, is located in Fort Wayne, Indiana. It has grown into the largest online seller of musical instruments and pro audio equipment in the United States and he expects to be doing a billion dollars in sales per year by 2020 .

In his book Start with Why, Simon Sinek asserts that it is important for a company to first communicate WHY it exists before explaining HOW the vision is realized and WHAT is offered to customers (Sinek 2013). Sweetwater's business practices can be viewed in the context of Sinek's model, beginning with how well the company communicates its WHY - that it is a company composed of musicians and gearheads that exists to help its customers achieve their musical dreams. HOW that vision for customer service is achieved is expressed in Sweetwater's motto, "Always do the right thing," and in the cultivation and training of its Sales Engineers. WHAT customers experience is an exceptional level of customer service.

A report is included on an experiment conducted with customers and employees, and a series of interviews done with Chuck Surack and the two vice presidents involved in hiring employees.

Keywords: Sweetwater, Apple, Chuck Surack, Simon Sinek, music retail, customer service

\section{The Sweetwater Story}

We begin with the story of Sweetwater's founder and CEO, Chuck Surack, and will then go on to look at three aspects of the success of his business: WHY Sweetwater is in business, HOW it is run, and WHAT it offers to customers. Sweetwater bases its business on relentless customer service. The company's guiding principle is to always do the right thing for the customer, which is at the core of what it calls "The Sweetwater Difference".

Surack started out as a saxophone player and played on the road for a number of years. In 1979 he started a mobile recording service from his Volkswagen van, which he would park outside venues, record shows, and then mix the tracks in his mobile home. By 1981 he had moved the studio to a small building on Getz Road in Fort Wayne, Indiana.

A major turning point in his career grew out of the purchase of a Kurzweil K250 synthesizer. It was the first keyboard to have sampled sounds, and offered realistic strings, brass, and choirs, which he used with clients who wanted to sweeten the recordings made in his studio. Ray Kurzweil's first invention was a reading machine for the blind, and he designed the K250 with accessibility in mind, in particular for the needs of Stevie Wonder. The controls of the keyboard were very tactile, and everything was controllable with buttons in order to avoid having layers of menus accessed on a tiny LED screen. There was an empty slot inside the instrument and Surack figured out how to reverse engineer the instrument and to increase the number of sounds by loading it with his own samples.

By 1985 he had written a computer program to edit the sounds and had become a Kurzweil dealer. He wanted to trade sounds with people, but no one was making their own. He established the Sweetwater Sampling Network to sell sounds for the instrument, and his customers soon included Stevie Wonder, Dolly Parton, Kenny Rogers, and Bob James. He became a technical resource for recording artists and by 1990 had five people working in his house and tour buses were showing up at all hours. He started selling Mark of the Unicorn Professional Composer notation software 
and then began offering the recording equipment requested by his customers.

In 1990 Sweetwater had moved into its first commercial location. A year later Surack had twenty employees. In 2006 they moved to the location they are in today where they have been growing steadily by $17-28 \%$ each year since 2010 . By 2016 Sweetwater had doubled in size and become the largest online seller of musical instruments and pro audio gear.

A permanent display in Sweetwater's lobby includes some of the equipment that Surack used since the early days of his recording business. It makes it clear that he is a gearhead, and his Boy Scout uniform hanging from the VW van's door represents his respect for the Boy Scout Law: "A Scout is trustworthy, loyal, helpful, friendly, courteous, kind, obedient, cheerful, thrifty, brave, clean, and reverent." Surack says these character strengths will stand a person in good stead in both their professional and personal lives.

Sweetwater is now adding about 70,000 new customers a month. There has been significant growth across all product categories, with the biggest increases being in pro audio, synthesizers, drums, guitars, and microphones. In 2017 they had $\$ 619$ million in revenue, sold 107,000 guitars, had 700 students in the Sweetwater Academy, and 1,132 employees. In 2018 they had $\$ 725$ million in revenue, sold 128,000 guitars, had 850 students, and 1,531 employees. By the end of 2019 they will have 1,550 employees, 500 of those being sales engineers.

The company doubles in size approximately every five years and is now entering its third phase of expansion. It has always been concentrated in one location, but this time considered creating a new facility in another state. In the end the tax incentives offered by Indiana and concerns Surack had that they might not be able to maintain the Midwestern values in its culture convinced him not to move. "We pedal fast and our clock runs a little faster than most other people's clocks. I think there's a real quality of life and an appreciation of employees that work hard that's probably part of Midwest values...I think the people here are just good and hard-working" (Surack 2019). This led to the decision to remain in Indiana and invest $\$ 76.4$ million in Sweetwater's 163-acre facility in Fort Wayne. By the end of 2020 the company will have added new space for product storage, gear testing and photography, offices, staff amenities, and customer pickup, along with 350,000 square feet of new warehouse space and a 30,000 square foot event center. They will be creating 1,000 new jobs by 2024 .

\section{Start With WHY}

In his book Start With WHY Simon Sinek asserts that there is an advantage to communicating WHY a company is in business before explaining WHAT it does and HOW it does it. WHY is a purpose, cause, or belief. Sinek says that it should appeal to the non-verbal limbic center of the brain. He says that people make decisions there based on non-verbal emotions, after which the rational mind finds good reasons for them. Sweetwater's business model can be viewed in the context of this model, and whether it communicates to customers WHY it is in business.

Sinek cites the example of Apple since so many people are familiar with that brand. Apple started as part of the counter culture in 1976. Its two founders, Steve Jobs and Steve Wozniak wanted to empower individuals. Jobs said that, "There are monster computers lurking in big business and big government that know everything from what motels you've stayed at to how much money you have in the bank. But at Apple we're trying to balance the scales by giving individuals the kind of computer power once reserved for corporations" (Jobs 1997). For him, computers were "bicycles for the mind" that could help advance humankind. Apple used to start with WHY before it talked about HOW it did things and WHAT it sold, unlike other computer companies that start by talking about the specs of its products and why they are better than the competition - an approach that Sinek says turns products into commodities and drives prices down. Starting with WHY helps companies connect with people who believe in the same things that they do, who then turn into loyal customers willing to pay a higher price and/or put up with inconveniences.

Jobs was fired in 1985 but invited back in 1997. When he returned, he made it clear what Apple's core value was when he introduced the "Think Different" campaign:

Our customers want to know who Apple is and what is it that we stand for. Where do we fit in this world? What we're about isn't making boxes for people to get their jobs done, although we do that well, we do that better than almost anybody in some cases. But Apple is about something more than that. Apple's core value is that we believe that people with passion can change the world for the better. We've had the opportunity to work with people like that, with software developers and customers who have done it, in some big and some small ways. We believe that in this world people can change it for the better, and that those people that are crazy enough to think that they can change the world are the ones that actually do. And so, what we're going to do in our first brand marketing campaign in several years is to get back to that core value. A lot of things have changed. The market's a totally different place than it was a decade ago, and Apple's totally different, and Apple's place in it is totally different, the products, manufacturing, and distribution strategy are totally different, and we understand that. But core 
values shouldn't change. The things that Apple believed in at its core are the same things that Apple stands for today. (Steve Jobs 1997)

Apple introduced the Macintosh computer in 1984. It was the first mass-market personal computer with an integrated graphical user interface and mouse. It was intuitive for customers to use because they didn't need to know a lot of text commands like those used in Bill Gates' MS-DOS operating system developed for the IBM PC. Jobs was a music lover, and Apple wanted to build products that Apple employees themselves would use. The iTunes store and iPods had the capacity to put a thousand songs in your pocket and moved the music business from albums to singles. The success of the iPod financed the development of the iPhone.

Surack and other members of the executive team admire companies like Disney and Ritz-Carlton that exceed customer expectations (McDonald 2019):

Apple was a great company during the Steve Jobs years. I like their design philosophy in general - the simplicity, and that they were remarkably different from Microsoft. In fairness, the rest of the world has caught up with them. Everyone copied them and is nipping at their heels, and there are a lot of great companies making a lot of great products today. There have been some others through the years. Everyone talks about Nordstrom. There used to be a hard drive company called APS whose philosophy I loved...I love anything that's done well, anything to extremes. It's the same with events I like to see, whether it's sports or music. I don't care what the genre is, I just want to see it done really well.

I admire some of the higher-end cars and what it takes to engineer, market, and sell them - who their customer base is. I' $m$ really impressed by cars like Porsche. I also like Hondas. In the aviation world there's a line of airplanes called Cirrus Airplanes. They have redefined personal aircraft from my point of view. Everybody was flying Cessnas and Bonanzas. This is a modern new airplane with a parachute and modern avionics. They're very customer service-centric.

Yamaha is a phenomenal company. I went to visit them three or four years ago and met their president. I had always thought their products were dead reliable and sounded good. But after going over there and seeing the kind of things they do technically and the way they think I came away dumbfounded and even more impressed. People have no clue what they do, from simple things like having a room where they heat a product up and then freeze it, and then heat it up and freeze it again, just to see what the effects are of the cycle. They vibrate the products. That's not that unusual in manufacturing, but it doesn't happen in our industry. There's a reason that Yamaha products are more reliable than other brands. (Surack 2019)

\section{WHY}

Chuck Surack started out as a touring musician. Like many Sweetwater employees, he remains an active performer playing one hundred shows a year in two bands. Sinek says that employees who understand WHY a company exists, and believe in the same things, work harder and stay on longer. In the careers section of its website Sweetwater explains its WHY for prospective employees: "Since 1979, we've helped music makers all across the world build their dreams. We are a team of gear heads who are committed to doing the right thing for our customers." In interviews Surack explains that two thirds of his employees are musicians themselves, and that he wanted to offer his friends the type of retail experience that he had always sought as a customer.

When asked WHY he started the company, Surack answered:

I'd been on the road for five years and wanted to come home, and recording was something that I knew how to do. I loved playing music... and being around musicians, I'm a musician myself. There wasn't that sort of recording studio service in the area. I was fortunate that there was a job that was my vocation as well as my avocation... The big 10,000 -foot view of WHY is I just love helping people fulfill their dreams. I don't think of myself as selling equipment as much as I sell the dreams and aspirations people have...I love watching people get successful with their music, whether it's commercially successful or just personally successful. I'm thrilled with that, helping them fulfill their dreams. (Surack 2019)

Jeff Radke, Executive Vice President of Sales and Chief Sales Officer, was working for another company when he first met Surack:

The very first time I called on Sweetwater, a rep took me to his house. That was something I wasn't used to. I walked in and met Chuck, there were dogs sleeping by the stairs. I got a chance to talk with him, I think it was just him at the time. His WHY was that he was a musician and a studio owner and wasn't able to find a company that could help with 
a sale adequately, to find out what was available, what he should have, and support him after the sale if he had problems or questions or something broke. There were a lot or retailers, and still are sadly, who just sell boxes...He kind of stumbled into it with the K250 and becoming a dealer for Kurzweil. His idea was that he could provide what he had been missing. He is able to take care of customers long term by actually caring about them and developing relationships, not just selling boxes, but rather being a place where they can call back later and say, "Oh, my God, this thing doesn't work," or "I've got this new issue," or ask a question and get to talk to the same guy. (Radke 2019)

Seth Godin says you can't market to the bulk of people in the center of a product adoption cycle because they are really good at ignoring marketing messages (Godin 2007). You should instead try to reach the innovators and early adopters who are the only ones interested in new things, because they will listen and if they like it will tell other people about your product or service and do your marketing for you, which can lead to its acceptance by the mass of consumers in the middle of the bell curve (Figure 1).

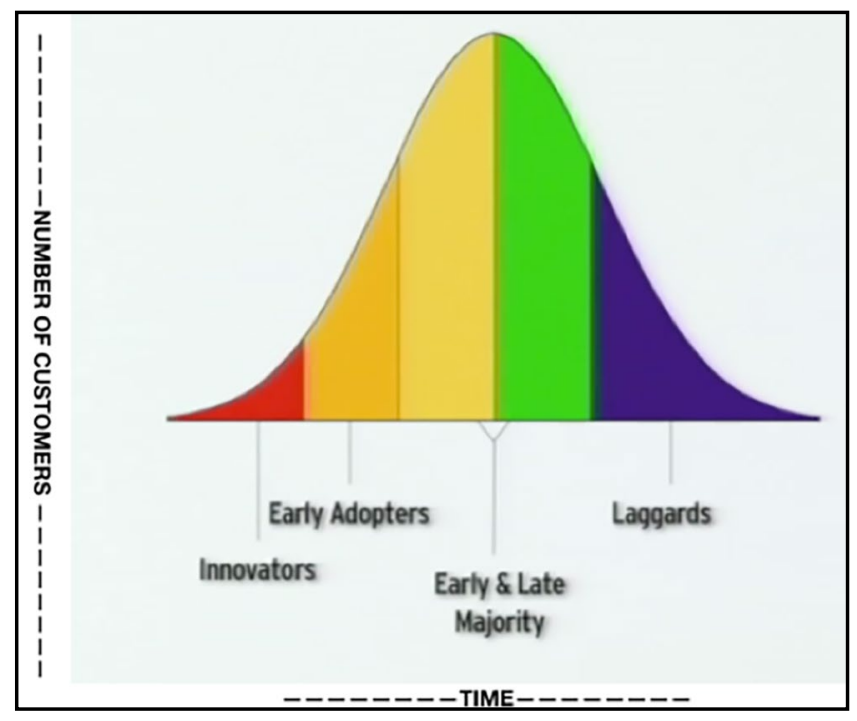

Figure 1. Adopter curve (Godin 2007).

Apple began to communicate less about their WHY after Steve Jobs died, and Sweetwater is talking primarily about HOW they offer great customer service. Maybe WHY is only needed to connect with early adopters, when the vision can be expressed by the founder before they get too busy running a growing business.

\section{HOW}

There is much more emphasis placed on the Sweetwater website and printed marketing materials on HOW it offers the highest level of customer service and support — an ap- proach that is expressed in the term "The Sweetwater Difference". The approach to building its customer base is in line with Godin's strategy: "At Sweetwater, we have one single goal in mind: to make you a satisfied customer. That single focus, driven from every aspect of the company's operation, is the key to our ongoing success. If you're a satisfied customer, you'll come back to us when you have additional gear needs in the future, and you'll tell your friends about us. Then if we can make them satisfied customers, the cycle continues."

On "The Sweetwater Difference" page it says, "From day one Chuck was committed to providing a retail experience for his customers that was unparalleled, the sort of experience he always sought as a customer."

HOW the Sweetwater Difference is achieved is encapsulated in the motto, "Always do the right thing." Jeff McDonald, Sweetwater's Senior Vice President of Human Resources recalled how it came about:

When Jeff Radke, Jeff Ostermann, and I sat down eight or nine years ago to write a concise, accurate and enduring mission statement, "Do the right thing" was already a very deeply embedded part of our culture. We didn't go hire a bunch of consultants to come up with a mission statement and a slogan. We sat and tried to boil down and encapsulate what we've always done. From the very first month I worked here it was, "Just use common sense, use good judgment, and do the right thing." We looked for the common denominator in everything we had written. It was "Do the right thing." That's what we do every day. It was easy to get there, and the process was organic. (McDonald 2019)

When asked where "Do the right thing" came from, Surack says it was not from a sudden flash of insight but rather just the way he grew up in his family and church:

Growing up as a Boy Scout is what really set the tone for me. A Boy Scout learns to be trustworthy, loyal, friendly, courteous, kind, obedient, cheerful, thrifty, brave, clean, and reverent. Those are amazing principles to live by personally and professionally. I learned to always give back and help others, leave the place better than you found it, to make things better. The Japanese have a term kaizen which means continual improvement. That's where my head is, that's where my heart is, and so when I started the recording studio in 1979 out of the VW bus, I always tried to find ways to add value for the customer. That meant things like charging for a little less time than I actually used, giving them extra cassettes or albums, just being all in, all in, all in. 
Fast forward forty years later to today and it's the same thing, whether that's the two-year warranty that we offer, fifty people in our tech support department, or the 55-point guitar inspection. None of our competitors do any of that. It's a way for me to add extra value. (Surack 2019)

Sweetwater employees also strive to exceed expectations. When asked where that habit came from, Surack replied that it, too, came from his childhood:

That goes back to Boy Scouts and just always doing things the best that you can. If it's worth doing, do it well. Don't just do it halfway or part way...I've always tried to do the right thing, it's pretty simple. I can't imagine not doing the right thing, frankly, I wouldn't know how to do that. I can remember as a five-year-old when I made potholders and would sell them for fifteen cents for one or two for a quarter. If you didn't exactly go up and down correctly you would miss a loop, which was a mistake. If that happened, I would pull the whole thing apart, even if it was the last step. I would pick it all the way apart and fix it, because I wasn't going to put it out if it wasn't perfect. That was "Doing the right thing." (Surack 2019)

When hiring for Sales Engineer positions, Jeff McDonald looks for people with technical skills who are also good communicators:

Soft skills are on the decline, and SAT scores are down even though they dumb-downed the test. I think it's a result of cell phones. One of the tests that we give in marketing and sales is to give applicants an email from someone interested in some product and ask them to compose an email reply. We look at how fast they can type. We're not trying to be elitist, snobbish, or academic about it, we just look at what they're going to do all day. They're going to talk to fifty people on the phone, go into our CRM system and take really good notes about those conversations so that the next time they talk to the same person they can refer back to what their last conversation was. It's not going to work if they can't listen, type, take good notes, and send you an intelligent email when you ask a question. They have to be able to follow directions and process information.

We give them a letter that's filled with spelling and grammatical errors and ask them to correct it. Obviously, computers have spell checks, but we want to see if they can string five sentences into a paragraph and know when to start the next one. In the fourteen years that skill keeps dropping. Does that mean the students are dumber? No, not at all. They can run circles around me on a computer. It's just a different skill set.

Let's go back to the WHY to come full circle. If the WHY is Chuck saying, "I want to help my friends make better music," then how do you do that? How do you make that experience better? It starts with listening to what the customer needs and wants so that you can help them, and then in the clearest and most professional, friendly way you can, help them. Any way you cut that it's going to involve communicating back to them. If you can't do that, then I don't care if you get $100 \%$ on the technical test, because it's not going to do me or the customer any good. The guy that got the best score ever on the technical test that we give as part of the interview process was a Ph.D. that taught music technology. He was the worst Sales Engineer in Sweetwater's history. He had all the knowledge, but he couldn't communicate it to the average customer. First of all, he didn't want to talk to them. He wanted to write them a 10-page dissertation on whether they should buy an SM57 or an SM58. It was a train wreck. He knew everything, but he couldn't communicate except on his terms. After about a year and a half he realized he couldn't talk to the customers, they were too dumb. If you can't communicate you shouldn't be in a job that's all about trying help people make a decision, because that's why they're coming to us. We're the experts who can help them with that. You have to be more than an expert, you have to be an expert communicator. (McDonald 2019)

In his interview, Radke reinforced the importance of both written and verbal communication skills:

Something many (most?) students probably haven't thought about much is that they will need to have highly developed communication skills... in every way. That means being able to write in a professional way, type very rapidly, and perhaps the most difficult of all, be comfortable and delighted to speak with hundreds of people every day. Voiceto-voice and person-to-person is the most effective way to communicate, period. (Radke 2019)

Sweetwater Sales Engineers grow their base of 4,000 to 6,000 customers with whom they are on friendly terms. 
Sales Engineers are knowledgeable and authentic and provide unbiased recommendations. In every touch customers have with the organization they talk to the same person, whose goal is to form a personal relationship based on trust, loyalty, and expertise. Employees are expected to tell the truth and admit and fix any mistakes they make, and to let customers know when they don't have the answer to a question and then get the information for them.

Those hired for Sales Engineer positions go through Sweetwater University-an intensive thirteen-week training program which is said to be like a master's degree program in music retail products. There are 300 classes and 100 teachers, and the pace is described as "drinking from the fire hose." Surack has always been more interested in developing relationships and turning customers into friends. It is not unusual for a Sales Engineer to inform a customer that there is a less expensive and possibly more effective way to fulfill the need than the one they called wanting to buy. The day he was interviewed he had talked with a group of new Sales Engineers in one of their first days at Sweetwater U:

It sounds awful from a business guy, but I don't care if we make money on the first, second, or third sale, what I'm interested in is doing the right thing for the customers, treating them well. The money, referrals, and repeat business will come. I just want to be able to lay my head on the pillow at night and know that I've treated people the way I would like to be treated. My real point to them is that I am empowering them to think the same way. I promised them that they would not get in trouble if they replaced something, or paid for an Uber ride, or bought lunch, and that in fact that they would get in more trouble if they DIDN'T do that, and that if they ever get into any bit of trouble from any manager they can just pull the Chuck card and say, "No, no, Chuck said I wouldn't get in trouble." (Surack 2019)

Jeff Radke is another member of the executive team who talks with employees as they begin their training. He explains the technical information covered in Sweetwater U.:

I meet with everyone and help them start to mentally prepare the mindset, understand how the approach should work, the WHY of what we do in Sweetwater U. and why they should pay attention in order to get them off on the right foot. Sweetwater U. is constantly evolving. We did another major revision for this year. We tried to steer it a little away from brands and products and back to understanding the technology more broadly. For example, If I understand how an optical compres- sor from manufacturer A works, then I will be able to apply that to the ones made by manufacturers B, $\mathrm{C}$, and D. Roughly half of the classes are about the technology side, and we cover every aspect of it so that every Sales Engineer is well-versed in all our products since we are so relationship-oriented. The areas of study include analog, digital, keyboards, MIDI, synthesis, drums, guitars, lighting, and the DJ market. Recording and PA is still our heart, if you will, so we also cover the live sound, recording, and pro audio side of things. That's the technical part, and we have manufacturers come in and teach that. (Radke 2019)

One of the sales techniques that Sweetwater uses is called "The Perfect Conversation" which flows like an upside-down triangle, where a lot of information is gathered over the course of a phone call and possibly funnels down at the end to a recommendation of a specific product that best matches the customer's need. At that point price is no longer the main consideration. Radke explains that HOW the company does business and differentiates WHAT it offers customers at some point in the conversation. This seems to align with what Sinek says in his book about solidifying customer loyalty through balancing HOW and WHAT with WHY the company is in business:

The way we sell is very different from the norm, which is when the customer asks, "What's your price?" you get them a price. If we did it that way, we'd actually be doing them a disservice, because we wouldn't be figuring out what they really needed. For example, they may have read in a forum or heard from a buddy about some great microphone, or seen one in a studio. When they ask us how much it would cost our response is going to be, "That's a great mic. What are you going to be using it for?" We're going to find out what gear they own, if they're in a band, if they're going to use it live, what they're going to attempt to do with it, what their budget is, all the critical things for them, and in the process of that we're also going to let them know who we are. If they want to buy a guitar, we're going to talk about the 55-point guitar evaluation, and the fact that we have a temperature and humidity-controlled warehouse, luthiers on staff, a whole guitar workshop, and about the relationships and training we have from vendors. Helping the Sales Engineers learn how to communicate with the customers is a huge part of that part of Sweetwater U....Maybe my customer plays guitar but her son is a keyboardist. Maybe he was an infant when the 
Sales Engineer started dealing with her, and now he's starting to take lessons. Unless I continue to maintain that relationship, I'm never going to know that her kid is playing keyboards now. I have to keep asking those questions.

I also really have to keep differentiating, from a business perspective, how Sweetwater is different. One of our senior guys, Kenny Bergle, has been here about twenty-six years. He can be talking to someone he's been dealing with for fifteen years and I will occasionally hear him say something like, "That's a great thing about Sweetwater," and then he'll talk about tech support. If you've got a problem with your system, we'll take care of it. We're not going to be like the manufacturer who will only take care of the thing that is theirs, we'll help you solve the problem with your system. If there's a clocking issue and you have an Apogee converter and Avid's Pro Tools and they're not communicating well we're going to help fix that, we're not going to say, "Well, it sounds like the other guy's problem." We're just going to take care of it. The Perfect Conversation always includes qualifying, differentiating, and selling ourselves. Mac Hatton can talk about working at a big studio in Nashville. Now all of a sudden, we are differentiating ourselves and we're not just a kid in a black t-shirt and ripped up jeans that you typically find employed in a music store, we're serious professionals who are studying on an ongoing basis. (Radke 2019)

Sweetwater Sales Engineers are paid on commission and it is up to each one to decide how much money he or she wants to earn. Radke came to Fort Wayne with a history of helping employees set goals, something that they are given more autonomy to do at Sweetwater. Each Sales Engineer is given the tools, support, and freedom necessary so they can all think and work as if they are operating their own store:

The life skills part could include me going over The Seven Habits of Highly Effective People, which I think is great not only here but for outside of work. I do a class on goal setting. Most humans never set any sort of written goals at all. I talk about why it's important and help them understand the process, and hopefully get them in the position where they'll be doing that for themselves and for their families. One of the things that we do that is really unusual, I don't know of anyone else that does this in our industry, is that the goal setting helps Sales Engineers set their own goals, and then our Chief Financial
Officer and I build the company goals off of that. They will say how much money they are going to make, how many calls they need to make because of that, how it's going to be weighted from month to month in order to work around their vacation plans, the attachment rate, return rate, talk time - all the meaningful metrics. We're not just preparing them to go out on the sales floor, we're preparing them to run their own business. (Radke 2019)

Sweetwater spends more time training its employees than many Guitar Center salespersons last on the job, and as a result has the best trained salespeople in the industry. In addition to ongoing continuing education there is a Sales Resource Center where employees can check out equipment to try out at home:

It started in my office in the old building where I had equipment that Sales Engineers could check out for a while. Now it's much more organized, there's over a half a million dollars' worth of stuff in there, like big PA speakers, a little system for a coffee shop gig thing, tons and tons of pedals, guitars, you name it. We have an SSL console that you can check out. It took four guys and three vehicles to figure out which one it would fit in. They got it into this guy's house, and now he has other Sales Engineers coming over and they've got it plugged in and are listening to it and getting in deep and really understanding it and figuring out which customers it would be good for, how it sounds with their monitors. The same thing goes with microphones. You can take home five really nice condenser microphones and then when you're talking with a customer the next day you can say, "I was using a 251 and a U47 and a C12 and here's what I liked about each one in different situations. I'm using Genelec monitors." The customer realizes that you are actually using that stuff in your studio instead of dealing with some dude hanging out in a music store. (Radke 2019)

Sinek says that employees who share the same vision as the management of WHY the company is in business are more productive and stay on for a longer period of time. Sweetwater employees seem to share the company's ideals, which makes it possible for customers to talk with the same Sales Engineer each time they call. The shared vision seems to be reflected in the fact that there is a low rate of employee turnover:

I think part of our power as a company is the continuity. Year-to-date I think we're at maybe $4 \%$ turn- 
over, which is ridiculously low. Retail turnover is $50,60,100 \%$. Our average tenure is well over five years, maybe over six years at this point. If I'm a customer I have the comfort level of having an inside person that is going to take care of me. (Radke 2019)

\section{WHAT}

WHAT a company does is what ends up as the being seen by customers. The Sweetwater Difference of doing the right thing manifests in a number of ways, starting with conversations customers have with Sales Engineers to help them pick the right gear, followed by ensuring that their orders ship smoothly and are received with satisfaction. Jeff McDonald explained some of the advantages that Sweetwater's scale and investment in training offer over independent music stores located in communities across the country:

If you go to your larger independent store looking for a guitar, they may have both Fender and Gibson and some inexpensive $\$ 200-\$ 300$ guitars in order to offer a lesson program. They're not going to have fourteen brands of electric guitars. They might have Taylor or Martin or Gibson, but probably not all three, unless it's a really bigger store. They surely don't have 300 microphones and every DAW known to man. Part of it is just that we can offer so many more products. We have 34,000 products on the website, where a typical independent music store has probably a couple hundred. The customer can see everything they're interested in, and the people they talk to are experts. The Sales Engineers come from a music tech program, then we put them through thirteen weeks of classroom training, and then they have three hours of formal product training every week after that. Almost every day there are vendors here for a day who set up a petting zoo to let the Sales Engineers talk to them about new products and get trained on them. Within two years the graduates of your program are within the top $2 \%-3 \%$ of audio experts in the country. There's no way you could do that in a store. The customer thinks, "34,000 products, the sales people are experts and really nice and fast, and I don't have to get in the car and go to a store to find out that they don't have PRS guitars there." (McDonald 2019)

Sweetwater's distribution center has a million-dollar conveyer belt and orders are said to be filled with $99.9 \%$ accuracy. Most orders include free FedEx shipping and arrive nearly anywhere in the U.S. in a matter of days since the company is located centrally. Most of the business is done by phone, but they also have a brick and mortar music store on site that is fully loaded with demo studios and the Midwest's most comprehensive selection of audio equipment and musical instruments.

The Piano Showroom features Yamaha and Roland acoustic and digital pianos. Customers can sell their gear on consignment or trade it in for in-store credit in the Gear Exchange. Guitars go through a 55-point inspection before going on sale, so they often leave Sweetwater in better shape they were in when they arrived from the manufacturers. Photographs are posted online of nearly every guitar from multiple angles so that customers can see each individual instrument in the Guitar Gallery along with serial numbers, so they know exactly which instrument they are getting.

The Product Optimization department adds extra value like custom sound sets, pre-installs firmware updates, and performs other gear tweaks. Sweetwater sells its own Creation Station Computers which are pro audio Windows PC audio production stations. Tech support is free and available around the clock, including help with making one product work with the others in a customer's system. Sweetwater has developed an online knowledge base called SweetCare that includes more than 10,000 articles.

Instead of trying to make more money off customers by getting them to purchase extended warranty coverage, Sweetwater automatically includes a free two-year "Total Confidence Coverage" warranty with nearly every product. Most repairs are handled in-house. Sweetwater is also involved in education. They offer workshops and year-round master classes.

The Performance Theatre has three sound systems: a 7.1 surround JBL system, individual jacks at each seat for headphones, and a virtual acoustics system with 80 speakers embedded in the walls allowing the acoustic environment to be instantly reconfigured to simulate a variety of different spaces. Employees and the public can perform in Crescendo Club located at the end of the dining facility. The Downbeat Diner offers restaurant quality food at cafeteria prices and the Crescendo Café provides ice cream, espresso, and baked goods.

There is a Concierge Service that helps visitors, arranges tours, and handle employee perks like dry cleaning and assistance in planning family outings. A general practitioner is available in the Health Clinic to treat illnesses and provide annual checkups for employees and their families. No paperwork has to be filed with insurance companies. Employees and the public can get haircuts, manicures, and massage therapy at the Wavelengths Salon+Spa, and play free pool, virtual golf, and arcade games in the Game Area.

A metal slide is a fun way to come downstairs from the sales department on the second floor. The building is green and LEED certified. It includes locally-sourced recycled 
and rapidly renewable woods, natural light, water conservation, and a high-quality ventilation system. There is a personal trainer in the Fitness Center, and employees can enjoy the racquetball court. They can also check out video games, and DVDs.

The 24,000 square foot outdoor Performance Pavilion was needed to provide a place where all employees could meet together. It also operates as a performance venue that accommodates 3,500 people and is also used for shows open to the community.

GearFest takes place over a Friday and Saturday in June and is the largest music trade show in the United States that is open to the public. It is free and there are plenty of presentations to attend and celebrities to meet. 15,000 people turned out last year to see the products shown by hundreds of companies. You can drop off your guitar when you arrive and pick it up at the end of the day with a new set of strings installed at no charge. GearFest guests may also camp overnight.

Sweetwater has built up its website to be a major information resource for people interested in musical instruments and pro audio, whether or not they are in the market to buy something. Their comprehensive Glossary is a great resource for definitions of terms, and the newest area of growth is in videos demonstrations:

The idea behind them is not just to sell products, it is way more educational. They make about eight to ten of them a week, and there are four to five thousand on the website. You get to hear the product and see some performance and learn about the features. There's definitely an educational aspect. Some are generic and less product-specific. For example, there's one for keyboard players who aren't organists who want to learn some tricks on what to play to get an authentic organ sound. You would be shocked how many people get on the website every week and watch the new InSync videos. We get a ton of input from customers. Do we want them to buy the products? Sure, but it's not a car dealer thing where we yell, "We've got the new Buick X, come on down today!" and talk about price. Instead the person just says, "If you want more information, talk with your Sales Engineer" at the end. (McDonald 2019)

\section{Maintaining the Culture}

In his book Sinek says that the greatest risk to a company is success. As a company grows the founder is not able to make all the decisions and has less contact with employees. Surak says that there are others in the company that can share in making decisions and would be able to take over and maintain the culture in the future: "I've got a phenomenal set of lieutenants on the Executive Team that have been with me a long time - thirty years for most of them, and they know how I think. I've been pretty clear. It would be pretty easy for people around here to know what Chuck would do if I were gone. I think it's going to continue for a long time" (Surack 2019).

One way that the Sweetwater culture is maintained is through coaching. McDonald explains one aspect of ongoing supervision of Sales Engineers:

Once they're released to the sales floor, they get constant follow-up from at least two different sales managers who observe what they're doing and look at all the numbers and listen in on phone calls. That typically goes on for three to four months. Then they go to a coach, who is also a sales manager, who will continue to monitor how they're doing. There isn't a formal schedule after that, it becomes much more individualized after six months. Some people need a lot of help, others are self-sufficient and do pretty well. Even Sales Engineers who have been here for fifteen to twenty years are still meeting with a coach. Our theory is that you can always learn something, grow, and do better. It's part of Chuck's whole kaizen philosophy." (McDonald 2019)

In addition to the supervision that sales managers perform, Radke has developed a system of clustering Sales Engineers in groups:

When I first got here I knew everyone and what they were doing outside of work, knew their families reasonably well, but we got to the point where I couldn't do that, which I find very frustrating but it's just the reality once you start to grow. Somebody could be doing really well here at Sweetwater from a work perspective, but their life could be falling apart outside, which would eventually cause them to leave. I wanted to build a safety network and make sure that anyone that was coming in could maintain that family vibe. I started dividing the sales team into "neighborhoods." Every neighborhood starts out with about ten people and may grow to fourteen or fifteen before I have to divide them up again. Within each neighborhood there are a couple of leaders. We are very big on autonomy here. I want to hire really smart people that have the right character, give them the tools, and then turn them loose. If I have to micromanage somebody, I made a mistake or they are having serious issues that we have to work through. The whole 
sales team nominates leaders, then the leaders are elected. They are typically going to be people who are well-respected and doing things the right way, they're being good teammates, $99 \%$ of the time they are already being good mentors to the new folks. I divide the leaders into neighborhoods so that there are two in each group, so that one person can be leaned on if the other isn't in, and they can work together a little bit to help the neighborhood. It's not a layer of management, it's a layer of leadership. They are the people who would probably have seen someone struggling and offered to help, saying something like, "I heard that last conversation and it didn't seem to go right, how about we try this?"

Within each neighborhood there's a range of tenure. There's room for brand new people and some very senior people. There's a spread of technical abilities as well, for example, having a crazy strong guitar guy or gal in every neighborhood, so if you get a question and don't know how that vintage neck compares with another, you can turn to that person and ask the question. There will be a big boy or gal PA person in each neighborhood. We take the loud people and spread them out, so we don't have eight of them shouting each other down in one neighborhood. We take it down to another level and start to look at the personalities within the neighborhood when deciding who to seat next to who. I might want to put someone who's been a little shy on the phone next to someone who has no problem dialing the phone and making those calls who can kind of mentor them. I have people who request to sit next to a particular person in order to learn from their style, or because "I work a lot with them, and we challenge each other constantly - can we stay together?" I move neighborhoods every year, so they move geographically on the sales floor. I keep the core mostly together, but inevitably as we grow, I have to start more neighborhoods, which gives me an opportunity to create more leaders.

I view those leaders as the Senate of the sales floor. They get some additional neighborhood leader lunches where we'll have someone from the Marketing Department come in and give them some behind-the-scenes perspective as to what's going on. We will lean on them a little bit at the beginning of the month when we have a postmortem of the previous month. We'll put a subset of the leaders, along with key stakeholders from Marketing and
Merchandising in a room to talk about what went well, and what didn't - which bundle or promotion was not effective, or what would be cool to do, so they're having direct feedback into the company's future in terms of how we market and the products that we have. We also have subsets of leaders do focus groups with the vendors. A lot of them come to us because we touch so many customers and ask what they are missing, what product should they be developing. These folks get some direct insight from the Sales Engineers to help them build products that will be great for our customers. We have 24,000-25,000 inbound and outbound calls per day. That is more points of contact than any manufacturer has over a long period of time, and we do that in one day. So, if they can talk with someone who is in touch with eighty customers a day, they are going to get some really good feedback.

One thing that keeps the small-company vibe alive and healthy is that the people in the neighborhoods take care of each other. If a call comes in for me and I'm out that day, that call will be offered first to my neighborhood before it goes to the whole sales floor, so they get really used to taking care of each other's customers all day long every day. Very often the Sales Engineers won't even take a split off of a sale to another Sales Engineer's customer, which they should frankly after maybe spending an hour with someone on the phone. They just say, "It's a karmic deposit, I know you'll take care of me next time, let's just roll." I've never experienced an environment like that anyplace else. In my previous lives I was a Director of Sales for AKG and was a regional sales manager. I've seen tons and tons of retailers, it just doesn't work like that elsewhere. The other reason that it really works here is that we hire very carefully, train really well to prepare them so I don't turn anybody loose after saying, "Here's how you write an invoice, here's how you write a quote, go sell something!" which is how I got thrown into it when I started. Our Sales Engineers are very well-prepared when they go in, and now they've got the system around them where their neighborhood's going to take care of them. If I'm gone today, I know that all my messages will be checked, all my emails will be checked and forwarded to my neighborhood. (Radke 2019)

\section{Experiment}

An experiment was performed about the awareness of 
Sweetwater's WHY and HOW. Questionnaires were distributed to 81 employees and 70 customers on June 21 and 22, 2019 at Sweetwater's GearFest. Customers were asked:

- Item 1: "What is "The Sweetwater Difference?" with the choice of possible answers being

- 1: offering low prices

- 2: Having the biggest selection

- 3: Fastest delivery

- 4: Doing the right thing (the "correct response")

- 5: Including candy with shipments.

- Item 2: "Why is Sweetwater in business?" with the choice of possible answers being

- 1: To offer low prices

- 2: To help musicians achieve their "dreams" (the "correct answer")

- 3: To make money and grow

- 4: To offer the widest selection

- 5: To be the best in the Midwest.

- Item 3: For how many years have you been a Sweetwater customer?

- Item 4: On a scale from 1 to 5, how much do you think of yourself as a musician?

- Item 5: On a scale from 1 to 5, how much do you think of yourself as a gearhead?

- Item 6: On a scale from 1 to 5, how likely is it that you will purchase something from Sweetwater in the future?

- Item 7: What is one thing that Sweetwater could do better for you?

- Item 8: What do you like best about Sweetwater?

Employees were asked the same questions, with the following substitutions:

- Item 3: For how many years have you worked at Sweetwater?

- Item 6: For how many more years do you plan on working at Sweetwater?

Afterwards, those customers who knew that Sweetwater's WHY is "musicians helping musicians" were asked how they knew the "correct" answer. They said they had figured it out on their own, that it wasn't something they got from promotional materials. Employees who were asked the same question said it is clear from the culture rather than being something taught during training. When interviewed, Surack said, "I don't think you're going to get a real clear opinion from employees about WHY I started the business. It's not something we talk about." Had the question been open-ended I expect there wouldn't have been as many cor- rect answers, which had been the case during an earlier pilot study when I asked customers and employees for a free response for WHY Surack had founded the company without prompting with a choice of answers to choose from. That had resulted in a variety of answers from employees, such as:

Sweetwater started out as a remote recording studio using the gear in the lobby. Chuck is a gadget freak, has his own home studio, and is passionate about riding the technology wave that is stretching out into the future. It's a company that offers superior customer service and satisfaction. Our motto is to "Do the Right Thing."

It's all about passion for Chuck. All the different companies that he's involved with, he only does the things he's passionate about.

I don't know why Chuck made the company.

We're a company that sells musical equipment.

We treat customers like friends.

However, when given a multiple-choice question on the questionnaire distributed during GearFest, most employees and customers picked the option stating that Sweetwater is made up of musicians helping other musicians achieve their dreams. Customers learn the WHY indirectly from conversations with Sales Engineers as they relate their own experience and provide personal recommendations of products that they have used themselves. Employees don't need to have Sweetwater's WHY drilled into them in training or supervision, it is just a core part of the culture of listening to customers and helping them find the best products for their applications. They know that most of their colleagues are musicians and that Surack himself continues to perform regularly.

The Sweetwater employees that were surveyed reported having worked at the company for an average of 5.58 years ( $\mathrm{s}=5.89$ years) with a range from 0 years (the current year being their first) to 26 years. Employees also reported wanting to continue working at the company for an average of $14.22(\mathrm{~s}=9.13$ years) additional years with a range from 0 to 50 additional years. Many simply answered that they planned to stay until they retired. Most employees stated that they work in phone sales $(n=43), 11$ reported working in-store sales, 10 reported working in an unspecified position, 4 reported working in merchandising, 2 each reported working in the warehouse, guest services, and maintenance, 
and one each reported working in service, concierge, bus driver, IT, and sales training. Further, 32 of the 81 employees responded with the highest rating (5 on a 5-point scale) for how much they identify as a musician; another 26 reported as the next highest level (4), and another 21 answered in the middle (3).

Employees demonstrated fairly consistent patterns of responses pertaining to WHAT the Sweetwater Difference is, and WHY the company is in business. That is, 77 of the 80 employees who responded to this question answered that the Sweetwater Difference was "Doing the right thing" (Choice \#4 for Item 1 on the questionnaire) and 78 of the 81 employees who responded to the question of why Sweetwater is in business responded with the selection "To help musicians achieve their dreams" (Choice \#2 for Item 2).

The following two charts (Figures 2 and 3) compare the responses of customers with only the upstairs phone Sales Engineers, the group that goes through the rigorous Sweetwater University training.

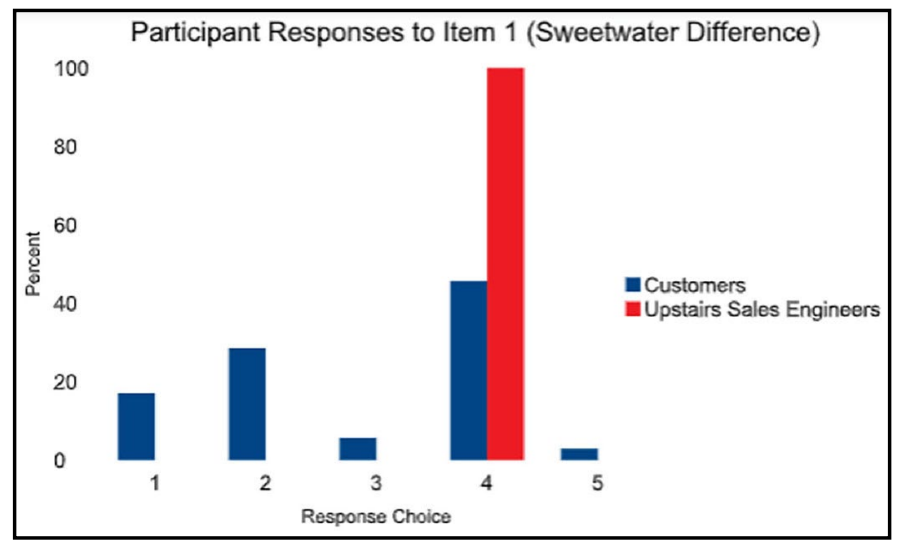

Figure 2. Participant response to Item 1 ("What is the Sweetwater Difference?").

Response 1: Offering low prices

Response 2: Having the biggest selection

Response 3: Fastest delivery

Response 4: Doing the right thing

Response 5: Including candy with shipments

Generally, employees provided substantive answers as to what they like best about Sweetwater (78 of 81), but only 41 of the 80 employees who responded to the item about what the company could do better provided substantive answers. These responses did not differ substantially across employee positions. Many customers and employees commented that they had difficulty coming up with something that the company could improve on and left that answer blank on the questionnaire. They had no such problem writing down something that they liked about it.

Customers reported having been customers for an average of 7.43 years $(\mathrm{s}=6.56)$ and also a high likelihood of making a purchase from Sweetwater in the future, 60 of the 70

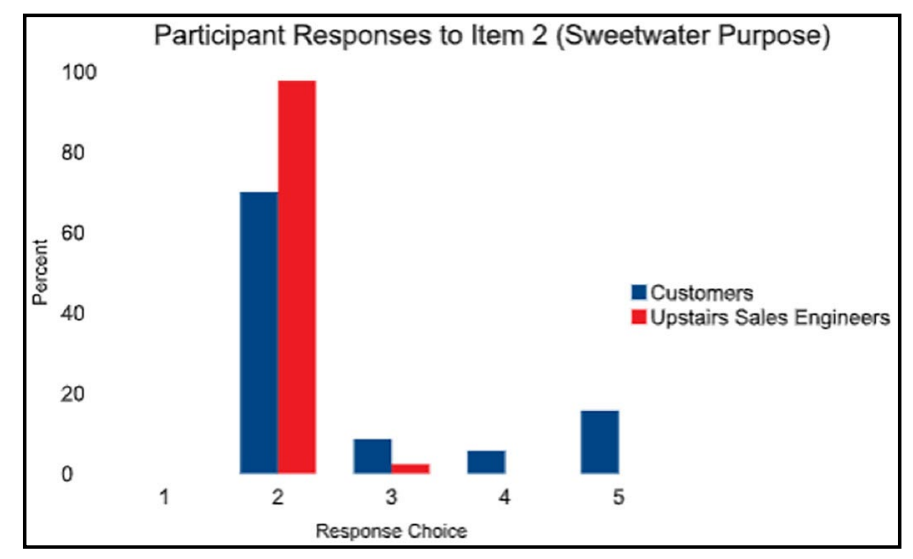

Figure 3. Participant response to Item 2 ("Why is Sweetwater in Business?").

Response 1: To offer low prices

Response 2: To help musicians achieve their dreams

Response 3: To make money and grow

Response 4: To offer the widest selection

Response 5: To be the best in the Midwest

respondents responding with a 5 on a 5-point scale. In terms of customer identification as musicians, only 19 responded being a musician on the highest level (5 on a 5-point scale) while another 28 responded with a 4; another 11 customers stated they identified as musicians as a 3. Conversely, 24 customers identified as being a gearhead with a 5, with another 17 with a 4 . Customers demonstrated a less consistent pattern with 32 of the 70 customers responding that the Sweetwater Difference is "Doing the right thing." Of the remaining participants, 20 responded that the Sweetwater Difference is having the largest selection and another 12 responded that it was offering low prices (response choice \#1). More customers - 49 of 70 respondents - stated that Sweetwater is in business "to help musicians achieve their dreams." The next most-selected response, with 11 participants, was "to be the best in the Midwest" (Response \#5).

Percentages of these responses are represented in Table 1 for the common items between both the employee and customer surveys such that the two groups may be compared. Table 2 includes the percentages for both the employee and customer groups pertaining to their responses to the questions about what they like best about Sweetwater and what the company can do better. When considering both groups, employees were much more able to state the Sweetwater Difference than were customers, but the highest selected response for customers was still "Doing the right thing," as was also the case for employees. This same pattern was found for the item pertaining to Sweetwater's reason for being in business, albeit much more pronounced for the customer group. Customers and employees did not appear to differ substantively in their self-ratings of being musicians or gearheads with the majority of responses in both groups reporting fours and fives on a 5-point scale. Finally, both 
groups were approximately evenly split in their ability to provide substantive feedback as to what Sweetwater could improve upon; the majority of both groups yielded substantive responses to what the company does well.

More phone Sales Engineers (28) responded substantively to what the company could do better compared to all other employees (13), as was predicted by Jeff McDonald. In addition to having the highest level of training, Sales Engineers had been with the company the longest and are therefore presumably the most familiar with Sweetwater's kaizen philosophy of continually improving how it operates.

\begin{tabular}{|c|r|r|r|r|r|r|r|r|}
\hline $\begin{array}{c}\text { Survey } \\
\text { Item }\end{array}$ & \multicolumn{2}{|c|}{$\begin{array}{c}\text { What is the } \\
\text { Sweetwater } \\
\text { Difference? }\end{array}$} & \multicolumn{2}{c|}{$\begin{array}{c}\text { Why is } \\
\text { Sweetwater } \\
\text { in Business? }\end{array}$} & \multicolumn{2}{c|}{$\begin{array}{c}\text { How Much of } \\
\text { a Musician } \\
\text { Are You? }\end{array}$} & \multicolumn{2}{c|}{$\begin{array}{c}\text { How Much of } \\
\text { a Gearhead } \\
\text { Are You? }\end{array}$} \\
\hline $\begin{array}{c}\text { Item } \\
\text { Choice }\end{array}$ & $\mathrm{C}$ & $\mathrm{E}$ & $\mathrm{C}$ & $\mathrm{E}$ & $\mathrm{C}$ & $\mathrm{E}$ & $\mathrm{C}$ & $\mathrm{E}$ \\
\hline 1 & 17.1 & 0.0 & 0.0 & 0.0 & 7.1 & 1.2 & 5.7 & 4.9 \\
\hline 2 & 28.6 & 1.3 & 70.0 & 96.3 & 10.0 & 1.2 & 17.1 & 6.2 \\
\hline 3 & 5.7 & 1.3 & 8.6 & 1.2 & 15.7 & 25.9 & 18.6 & 18.5 \\
\hline 4 & 45.7 & 96.3 & 5.7 & 1.2 & 40.0 & 32.1 & 24.3 & 27.2 \\
\hline 5 & 2.9 & 1.3 & 15.7 & 1.2 & 27.1 & 39.5 & 34.3 & 43.2 \\
\hline Total N & \multicolumn{1}{|c|}{70} & 80 & 70 & 81 & 70 & 81 & 70 & 81 \\
\hline
\end{tabular}

Table 1. Percentages of customer and employee responses to common items (note: $\mathrm{C}=$ Customer, $\mathrm{E}=$ Employee).

\begin{tabular}{|c|c|c|c|c|}
\hline Survey Item & \multicolumn{2}{|c|}{$\begin{array}{c}\text { What Could } \\
\text { Sweetwater Do } \\
\text { Better? }\end{array}$} & \multicolumn{2}{|c|}{$\begin{array}{c}\text { What Do You Like } \\
\text { Best About } \\
\text { Sweetwater? }\end{array}$} \\
\hline $\begin{array}{c}\text { Was Constructed } \\
\text { Response Substantive? }\end{array}$ & $\mathrm{C}$ & $\mathrm{E}$ & $\mathrm{C}$ & $\mathrm{E}$ \\
\hline No & 58.8 & 48.8 & 4.3 & 3.7 \\
\hline Yes & 41.2 & 51.2 & 95.7 & 96.3 \\
\hline Total N & 68 & 80 & 23 & 81 \\
\hline
\end{tabular}

Table 2. Percentages of responses to subjective items (note: $\mathrm{C}=$ Customer, $\mathrm{E}=$ Employee).

\section{Correlations}

A number of notable correlations arose in the data for both customers and employees with the latter group demonstrating a great deal more consistency than the former, and their self-identification as musicians correlated more strongly and positively with their likelihood of making a future purchase $(\rho=.416 ; p<.001)$. Additionally, a point-biserial correlation revealed that the extent to which customers identified as musicians correlated positively with whether or not they articulated a substantive answer as to what Sweetwater could improve upon $(\rho=.358 ; \mathrm{p}<.01)$.

Employees demonstrated much more consistency in their responses with a number of correlations arising within this group. Whether employees could identify the Sweetwater Difference was moderately correlated positively with their ability to state why Sweetwater is in business $(\rho=.39 ; p<$ $.001)$, their self-identification as gearheads $(\rho=.264 ; p<$ $.05)$, the number of years they wished to continue working for the company $(\rho=.319 ; p<.01)$, and whether their responses to what the company does best were substantive $(\rho=.307 ; p<.01)$. Further, employees responses to whether they could state why the company was in business were moderately and positively correlated with their self-identification as gearheads $(\rho=.299 ; p<.01)$; self-identification as a gearhead and as a musician were also moderately and positively correlated with one another $(\rho=.334 ; p<.01)$. Employees' responses to the number of years they worked for the company moderately and positively correlated with their self-identification as gearheads $(\rho=.243 ; p<.05)$ and their desired number of years to continue working for Sweetwater $(\rho=.256 ; p<.05)$. Finally, employees' self-identification as gearheads correlated more strongly with the number of years they intended to continue working for the company $(\rho=.469 ; p<.001)$. All correlations are shown in Tables 3 and 4.

The question for customers about the likelihood of making a future purchase was designed to measure customer loyalty. Sweetwater describes itself on its website as a team of gearheads who are "committed to doing the right thing for our customers." It is the author's opinion that emphasizing more that they are musicians (two thirds of them are) who want to help musicians achieve their dreams would be a better statement of WHY they are in business and resonate more with customers. The greater higher correlation between customers who self-identify as musicians and the prediction of making a future purchase compared with the loyalty of those who self-identify as gearheads seems to support that. Another indication that Sweetwater identifying itself as musicians rather than gearheads might lead to more feelings of shared common ground and belief in the same vision with customers is that both employees and customers have a slightly higher average for the rating of how much they identify as musicians (4.1 for employees, 3.7 for customers) compared with how much they rate themselves as gearheads (4.0 for employees, 3.6 for customers). Employees rate themselves higher on both scales than customers.

We thought that it was rather interesting that there were no significant correlations between the number of years as an employee or customer and whether a substantive answer was offered as to what the company can improve on. The relationship between years as a customer and the same outcome was somewhat stronger than for employees, but not strong enough to be significant. This seems to be a sign that new and longtime customers and employees are highly satisfied with the way the company operates. Comments from 


\begin{tabular}{|c|c|c|c|c|c|c|c|c|}
\hline & \begin{tabular}{|l} 
Sweetwater \\
Difference
\end{tabular} & $\begin{array}{l}\text { Sweetwater } \\
\text { Purpose }\end{array}$ & $\begin{array}{l}\text { Number of } \\
\text { years as a } \\
\text { customer }\end{array}$ & \begin{tabular}{|l} 
Musician \\
self-identifi- \\
cation
\end{tabular} & \begin{tabular}{|l|} 
Gearhead \\
self-identifi- \\
cation
\end{tabular} & \begin{tabular}{|l} 
Future \\
purchase?
\end{tabular} & $\begin{array}{l}\text { What can Sweetwater } \\
\text { do better? (Substan- } \\
\text { tive response?) }\end{array}$ & $\begin{array}{l}\text { What does Sweetwater } \\
\text { do well? (Substantive } \\
\text { response?) }\end{array}$ \\
\hline Sweetwater Difference & - & & & & & & & \\
\hline Sweetwater Purpose & -0.025 & - & & & & & & \\
\hline $\begin{array}{l}\text { Number of years as a } \\
\text { customer }\end{array}$ & 0.116 & -0.167 & - & & & & & \\
\hline $\begin{array}{l}\text { Musician } \\
\text { self-identification }\end{array}$ & 0.113 & 0.069 & 0.045 & - & & & & \\
\hline $\begin{array}{l}\text { Gearhead } \\
\text { self-identification }\end{array}$ & 0.022 & 0.050 & 0.135 & ${ }^{*} 0.266$ & - & & & \\
\hline Future purchase? & 0.202 & -0.080 & 0.029 & ${ }^{* \star \star} 0.416$ & 0.230 & - & & \\
\hline $\begin{array}{l}\text { What can Sweetwater } \\
\text { do better? (Substantive } \\
\text { response?) }\end{array}$ & -0.081 & -0.212 & -0.134 & 0.125 & **0.358 & 0.054 & - & \\
\hline $\begin{array}{l}\text { What does Sweetwater } \\
\text { do well? (Substantive } \\
\text { response?) }\end{array}$ & -0.266 & -0.141 & 0.179 & 0.000 & 0.000 & -0.066 & 0.187 & - \\
\hline
\end{tabular}

Table 3. Correlation matrix for customers (note: ${ }^{*} p<.05,{ }^{* *} p<.01,{ }^{* * *} p<.001$ ).

\begin{tabular}{|l|c|c|c|c|c|c|c|c|}
\hline & $\begin{array}{l}\text { Sweetwater } \\
\text { Difference }\end{array}$ & $\begin{array}{l}\text { Sweetwater } \\
\text { Purpose }\end{array}$ & $\begin{array}{l}\text { Number of } \\
\text { years as an } \\
\text { employee }\end{array}$ & $\begin{array}{l}\text { Musician } \\
\text { self-identi- } \\
\text { fication }\end{array}$ & $\begin{array}{l}\text { Gearhead } \\
\text { self-identi- } \\
\text { fication }\end{array}$ & $\begin{array}{l}\text { No .of years } \\
\text { to continue } \\
\text { working here? }\end{array}$ & $\begin{array}{l}\text { What can Sweetwater } \\
\text { do better? (Substan- } \\
\text { tive response?) }\end{array}$ & $\begin{array}{l}\text { What does Sweetwater } \\
\text { do well? (Substantive } \\
\text { response?) }\end{array}$ \\
\hline Sweetwater Difference & - & & & & & & & \\
\hline Sweetwater Purpose & ${ }^{* *} 0.390$ & - & & & & & & \\
\hline $\begin{array}{l}\text { Number of years as an } \\
\text { employee }\end{array}$ & 0.157 & 0.055 & - & & & & & \\
\hline $\begin{array}{l}\text { Musician } \\
\text { self-identification }\end{array}$ & 0.147 & 0.040 & -0.029 & - & & & & \\
\hline $\begin{array}{l}\text { Gearhead } \\
\text { self-identification }\end{array}$ & ${ }^{*} 0.264$ & ${ }^{* *} 0.299$ & ${ }^{*} 0.243$ & ${ }^{* *} 0.334$ & - & & & \\
\hline $\begin{array}{l}\text { Number of years to } \\
\text { continue working here? }\end{array}$ & ${ }^{* *} 0.319$ & 0.129 & ${ }^{*} 0.256$ & 0.115 & ${ }^{* * *} 0.469$ & - & & \\
\hline $\begin{array}{l}\text { What can Sweetwater } \\
\text { do better? (Substantive } \\
\text { response?) }\end{array}$ & -0.059 & 0.071 & -0.021 & 0.218 & 0.101 & 0.030 & & \\
\hline $\begin{array}{l}\text { What does Sweetwater } \\
\text { do well? (Substantive } \\
\text { response?) }\end{array}$ & ${ }^{* *} 0.307$ & -0.038 & 0.082 & 0.129 & 0.104 & 0.129 & & \\
\hline
\end{tabular}

Table 4. Correlation matrix for employees (note: ${ }^{*} p<.05,{ }^{* *} p<.01,{ }^{* * *} p<.001$ ).

customers to the last question about what they like about the company included statements such as, "They are helpful and friendly," "Best customer service hands down," "They do everything extremely well," "Sales reps know exactly what direction to point me in," and "Feels like they care." Employees answered the same question with comments such as "Making a difference in customers' lives and the amazing and smart people I work with," "Privately owned company that operates with morals," "Very easy to build your business on your own terms," "The challenge and reward of helping other musicians," and "They treat their em- ployees like human beings and are concerned with doing the right thing, not just making money."

\section{WHAT Else}

Surack has donated to over six hundred causes and serves on the boards of many non-profit organizations. He and his wife support almost everything in the region that is music or arts related, along with human welfare, feeding the hungry, and sheltering the homeless.

Sweetwater has partnered heavily with the University of St. Francis and Purdue University Fort Wayne to establish 
new music technology programs. This year 45 students began taking classes in its new on-site 8,000 square foot facility that includes a world-class studio, editing suites, and equipment library.

Surack wants to help create jobs in the area and has started the Sweet Family of companies. Several positions on the executive team are involved with maintaining the Sweetwater culture and its holistic approach to business and employee renewal. David Fuhr is Senior Vice President of the Sweetwater Experience and focuses on customer service, Kelly Byrd is Director of Leadership Development and Personal Growth, and Gerson Rosenbloom is responsible for the integration of the new Sweet Family companies into the Sweetwater culture. The eleven different brands are based on the same principle of doing the right thing every time:

- Sweetwater Sound, Inc.: The main operation

- Sweetwater Academy of Music \& Technology: Thirty teachers for instruments and recording giving individual and group lessons. There are also free acoustic jams and ukulele sing-alongs

- Sweetwater Studios: A state-of-the-art production house, designed by Russ Berger, staffed with producers, engineers, and session musicians

- Mynett Music: An instrument service supporting school music programs

- SweetCars: Sales and detailing of low-mileage luxury, sport, and exotic vehicles

- SweetHelicopters: Charter service for business and pleasure. Surack himself is a licensed pilot and occasionally commutes to work in one of the nine aircraft

- SweetAviation: Rental, flight school, thrill rides

- Aviation Specialty Insurance: Coverage for corporate and private aircraft and fleets, flight schools, and drones

- Longe Optical: Five locations, and the first and only vision care provider in the nation to offer an entirely in-house digital eye care experience

- Sweetwater Performance Pavilion: A 24,000 square foot covered outdoor venue for 2,200 seated or 3,500 standing patrons

- The Clyde Theatre: Chuck and Lisa Surack invested $\$ 9$ million in the restoration of the Clyde Theatre, a standing music venue for 2,000 people. It does the right thing for touring musicians as well as audiences by offering a high-quality sound system, dressing rooms, and hospitality facilities

\section{Conclusion}

Sweetwater does not put nearly as much emphasis on communicating WHY it is in business as it does on HOW the business operates. Not following Sinek's suggestion of starting with WHY does not seem to be negatively affecting the business as evidenced by its rapid growth, however, which seems to be limited more by the rate at which it can recruit, train, and provide workspace for qualified employees. However, even though Sweetwater does not explicitly state the company's vision as much as it talks about its dedication to customer service, both employees and customers recognize WHY the company is in business and HOW the business is run when prompted. Customers and employees seem to have internalized a good balance between the company's WHY, HOW, and WHAT, which is what Sinek says leads to loyal customers - the type that Sweetwater works to cultivate through serving customers and developing personal relationships.

Chuck Surack's commitment to doing the right thing and providing the type of retail experience that he himself would want, combined with the recruiting of employees who fit the culture and who then undergo extensive training has built a system and organization that delights customers and builds brand loyalty. Sweetwater has been growing rapidly and steadily over the years and seems to be in an excellent position for continued success. Surack is not predatory by instinct and wants other music stores to succeed in order to grow the music business. He is open about his methods and invites others to apply the same principles.

\section{Disclosure}

Ball State University is in Muncie, Indiana, which is located between Indianapolis and Fort Wayne, where Sweetwater is located. The company considers our Music Production and Telecommunications programs to be among their "farm clubs" and they employ seventy of our graduates. As a member of the music production faculty I have developed a friendly relationship with Jeff McDonald and the Human Resource department, and teach an open online class that is designed to prepare students for the technical exam (http:// willshare.com/courses/mmp280). The textbook for the class is Sweetwater's ProGear product catalog, which students use to work through one product category per week.

\section{Acknowledgment}

I would like to thank Tony Mangino for his suggestions on the design of the experiment and for his skillful and careful analysis of the data. 


\section{References}

Godin, Seth. 2007. "How to Get Your Ideas to Spread."

TED Talk. May 17, 2007. https://www.youtube.com/ watch? $\mathrm{v}=\mathrm{xBIVlM} 435 \mathrm{Zg}$.

Jobs, Steve. 1997. “"Think Different' marketing campaign." Presentation at a Town Hall meeting room Apple Computers, Cupertino, California, September 23, 1997. https://www.youtube.com/watch?v=keCwRdbwNQY.

McDonald, Jeff. Interview by the author. Sweetwater Sound, Inc., Fort Wayne, Indiana. May 20, 2019. http://www.rkwilley.com/uploads/4/2/1/4/42148419/ interview with jeff_modonald.pdf.

Radke, Jeff. Skype interview by the author. May 22, 2019. http://www.rkwilley.com/uploads/4/2/1/4/42148419/ interview with jeff_radke.pdf.

Sinek, Simon. 2013. Start with Why: How Great Leaders Inspire Everyone to Take Action. London: Portfolio/ Penguin.

Surack, Chuck. Interview by the author. Sweetwater Sound, Inc., Fort Wayne, Indiana. May 20, 2019. http://www.rkwilley.com/uploads/4/2/1/4/42148419/ interview_with_chuck_surack.pdf.

Robert Willey teaches music industry, songwriting, computer music, and senior projects at Ball State University. He has written books on music production, Brazilian piano, Creole fiddle, and the music industry, and is an expert on the music of the two most important composers from Texarkana: Conlon Nancarrow and Scott Joplin. He is currently working on mobile apps to support locally-owned businesses and to stream radio stations from around the world.

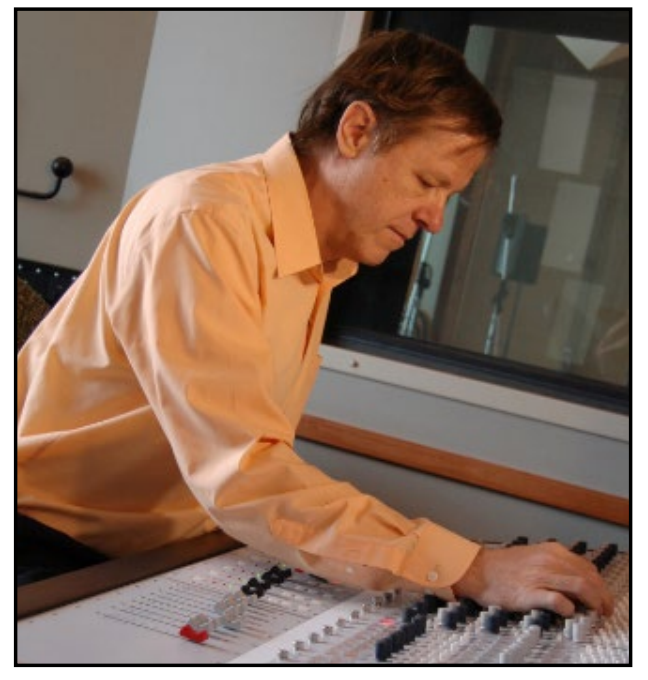




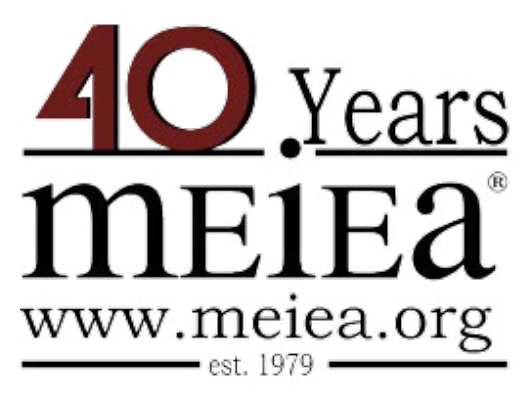

\section{PROCEEDINGS OF THE \\ 2019 INTERNATIONAL SUMMIT \\ OF THE \\ MUSIC \& ENTERTAINMENT \\ INDUSTRY EDUCATORS \\ ASSOCIATION}

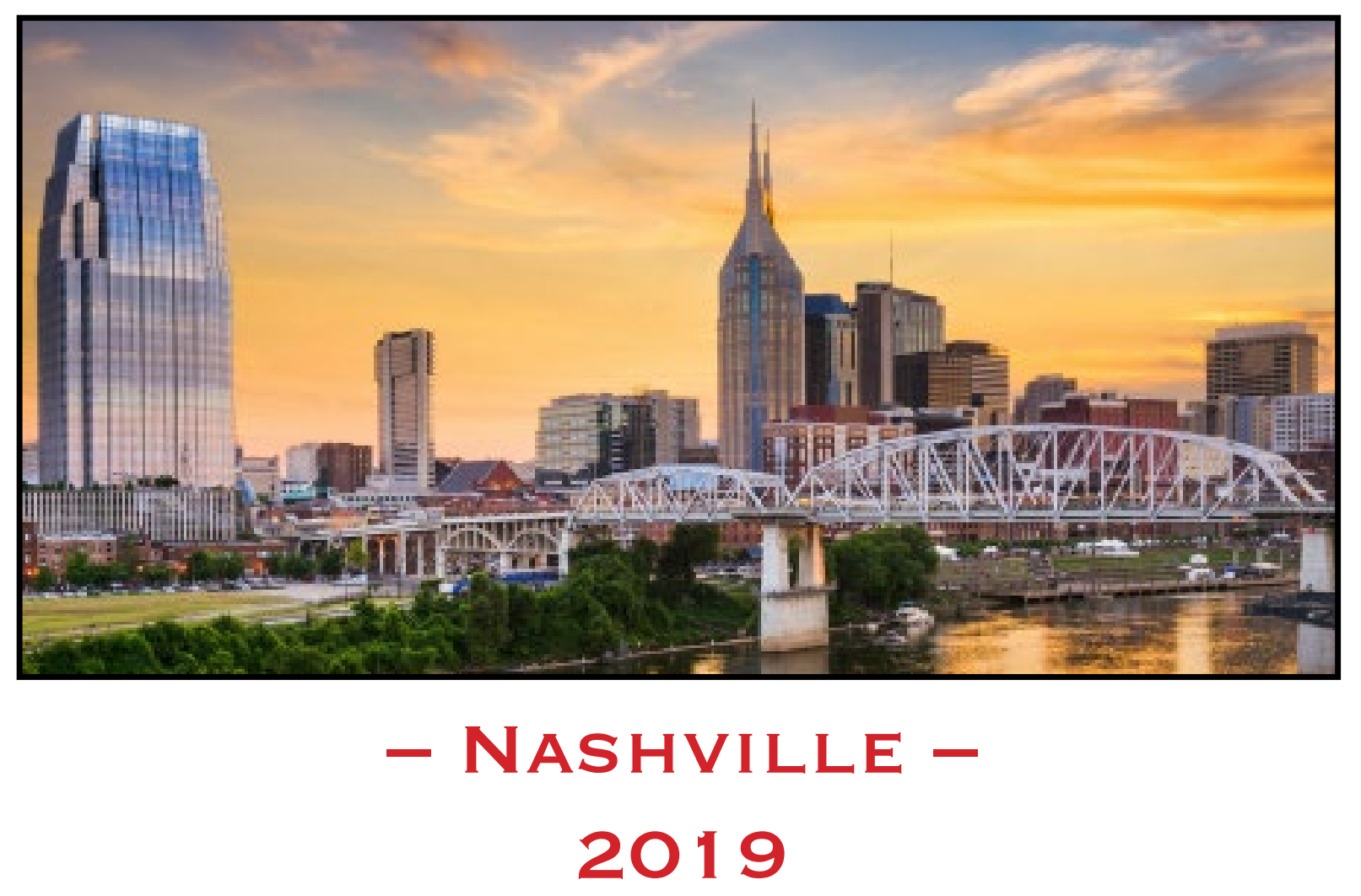

March 21 - 23, $2019 \cdot$ Belmont University - Nashville 